\title{
Loss of plectin causes epidermolysis bullosa with muscular dystrophy: cDNA cloning and genomic organization
}

\author{
W.H. Irwin McLean, ${ }^{1,9}$ Leena Pulkkinen, ${ }^{2,10}$ Frances J.D. Smith, ${ }^{1}$ Elizabeth L. Rugg, ${ }^{1}$ \\ E. Birgitte Lane, ${ }^{1}$ Florencia Bullrich, ${ }^{4}$ Robert E. Burgeson, ${ }^{5}$ Satoshi Amano, ${ }^{5}$ David L. Hudson, ${ }^{5}$ \\ Katsushi Owaribe, ${ }^{6}$ John A. McGrath, ${ }^{7}$ James R. McMillan, ${ }^{7}$ Robin A.J. Eady, ${ }^{7}$ Irene M. Leigh, \\ Angela M. Christiano, ${ }^{2}$ and Jouni Uitto ${ }^{2,3}$ \\ ${ }^{1}$ CRC Cell Structure Research Group, Cancer Research Campaign Laboratories, Department of Anatomy and Physiology, \\ Medical Sciences Institute, University of Dundee, Dundee DDl 4HN, UK; Departments of ${ }^{2}$ Dermatology and Cutaneous \\ Biology, ${ }^{3}$ Biochemistry and Molecular Biology, ${ }^{4}$ Microbiology and Immunology, Thomas Jefferson University, Philadelphia, \\ Pennsylvania 19107 USA; ${ }^{5}$ Cutaneous Biology Research Center, Department of Dermatology, Harvard Medical College, \\ Charlestown, Massachusetts USA; ${ }^{6}$ Biological Systems, Graduate of Human Informatics, Nagoya University, Nagoya, Japan \\ 464-01; 7 St. John's Institute of Dermatology, United Medical and Dental Schools, St. Thomas's Hospital, London SEl 7EH, \\ $\mathrm{UK}_{\dot{j}}{ }^{8}$ Experimental Dermatology Laboratories, Medical College of the Royal London Hospital, London E1 6BL, UK
}

Plectin is a widely expressed high molecular weight protein that is involved in cytoskeleton-membrane attachment in epithelial cells, muscle, and other tissues. The human autosomal recessive disorder epidermolysis bullosa with muscular dystrophy (MD-EBS) shows epidermal blister formation at the level of the hemidesmosome and is associated with a myopathy of unknown etiology. Here, plectin was found to be absent in skin and cultured keratinocytes from an MD-EBS patient by immunofluorescence and immunoprecipitation, suggesting that plectin is a candidate gene/protein system for MD-EBS mutation. The 14800-bp human plectin cDNA was cloned and sequenced. The predicted 518-kD polypeptide has homology to the actin-binding domain of the dystrophin family at the amino terminus, a central rod domain, and homology to the intermediate filament-associated protein desmoplakin at the carboxyl terminus. The corresponding human gene (PLEC1), consisting of 33 exons spanning $>26 \mathrm{~kb}$ of genomic DNA was cloned, sequenced, and mapped to chromosomal band 8q24. Homozygosity by descent was observed in the consanguineous MD-EBS family with intragenic plectin polymorphisms. Direct sequencing of PCR-amplified plectin CDNA from the patient's keratinocytes revealed a homozygous 8-bp deletion in exon 32 causing a frameshift and a premature termination codon $42 \mathrm{bp}$ downstream. The clinically unaffected parents of the proband were found to be heterozygous carriers of the mutation. These results establish the molecular basis of MD-EBS in this family and clearly demonstrate the important structural role for plectin in cytoskeleton-membrane adherence in both skin and muscle.

[Key words: Plectin; cytoskeleton; muscular dystrophy; epidermolysis bullosa; MD-EBS; hemidesmosome]

Received April 11, 1996; revised version accepted May 29, 1996.

The hemidesmosome is an attachment complex that mediates adhesion of the basal keratinocyte to the underlying basement membrane (Jones and Green 1991; Garrod 1993). Hemidesmosomes are found in basal cells of stratifying squamous epithelia, such as the skin and cornea, and have a complex structure consisting of a cytoplasmic plaque associated with keratin intermediate filaments and a sub-basal dense plate that associates with the anchoring filaments in the basal lamina. Biochemical studies using isolated hemidesmosomes have

\footnotetext{
'Corresponding author.

${ }^{10}$ Permanent address: Division of Medical Genetics, Kuopio University Hospital, 70210 Kuopio, Finland.
}

identified five major components of the hemidesmosome, consisting of polypeptides with molecular masses of 500,230,200,180, and $120 \mathrm{kD}$ and designated HDlHD5, respectively (Hieda et al. 1992). HD2 and HD4 are now known to be identical to the $230-\mathrm{kD}$ bullous pemphigoid antigen (BP230) (Sawamura et al. 1991) and the 180-kD bullous pemphigoid antigen/type XVII collagen (BP180) (Li et al. 1993), respectively. HD3 and HD5 correspond to the $\beta 4$ and $\alpha 6$ subunits of $\alpha 6 \beta 4$ integrin (Stepp et al. 1990; Jones et al. 1991). HD1 has been studied extensively at the biochemical level (Hieda et al. 1992) and has been shown to localize to the cytoplasmic side of the hemidesmosome, in a distribution slightly above, yet almost indistinguishable from, BP230 at the level of the 
cytoplasmic periphery of the hemidesmosome inner plaque.

$\mathrm{HDl}$ was first described as a $500-\mathrm{kD}$ component of the hemidesmosome (Owaribe et al. 1991) and later as the $466-\mathrm{kD}$ autoantigen in an autoimmune blistering disorder (Fujiwara et al. 1992). An exceptionally large (466$481 \mathrm{kD}$ ) intermediate filament-binding protein, plectin, was recently cloned from rat C-6 glioma cells (Wiche et al. 1991). The plectin sequence has similarities to both desmoplakin and the $230-\mathrm{kD}$ bullous pemphigoid antigen, and has a wide tissue distribution, including the sarcolemma in the muscle (Errante et al. 1994). Plectin is reported to have a number of binding affinities for intermediate filament proteins, including vimentin, glial fibrillary acidic protein, neurofilament proteins, keratins, and lamin B (Seifert et al. 1992; Errante et al. 1994). Although plectin is widely expressed, its precise cytoplasmic localization appears to depend on both cell type and the antibody used. It can appear diffused throughout the cell as a cytoplasmic component, or in a restricted distribution as a focal adhesion protein (Seifert et al. 1992; Wiche et al. 1993). It is possible that plectin and HD1 may be the same protein because of their similar molecular weight (Owaribe et al. 1991; Wiche et al. 1991) and colocalization in hemidesmosomes (Nagle et al. 1995; R.A.J. Eady, unpubl.).

Epidermolysis bullosa (EB) is a group of inherited mechanobullous disorders of the epithelial basement membrane zone that manifest with blistering of the skin and mucous membranes. On the basis of the level of cleavage of the skin leading to blister formation, EB has been divided into three broad categories (Fine et al. 1991; Lin and Carter 1992). The simplex forms of EB are those in which blisters develop intraepidermally at the level of the basal keratinocytes, above the basement membrane. Junctional forms of EB are those in which blisters form within the basement membrane. The term dystrophic EB is used to describe forms of the disease in which blisters form beneath the basement membrane.

The molecular basis of several major forms of EB has been elucidated in recent years. The classic dominantly inherited forms of EB simplex are now known to result from mutations in the keratin 5 and 14 genes (Epstein 1992; Fuchs 1992; McLean and Lane 1995). The prototypic forms of lethal (Herlitz) junctional EB result from mutations in each of the three chains of laminin 5 (Uitto et al. 1995; Christiano and Uitto 1996a). Finally, all forms of both dominantly and recessively inherited dystrophic EB result from mutations in the type VII collagen gene (Uitto and Christiano 1992; Christiano and Uitto 1996a,b). Although the molecular basis of many of the classic forms of EB are now well understood, a small group of patients exhibit the formation of blisters in the region of the hemidesmosome, the ultrastructural classification and clinical severity of which have been referred to as "pseudojunctional" (Fine et al. 1991; Lin and Carter 1992).

Ultrastructural classification of $\mathrm{EB}$ has identified at least three groups of patients with EB whose blisters form at the level of the hemidesmosome and whose clin- ical phenotype is unlike any of the classic forms of EB. These include generalized atrophic benign EB (GABEB) (Hintner and Wolff 1982), EB with pyloric atresia (EBPA) (Lestringant at al. 1992), and EB with muscular dystrophy (MD-EBS) (Niemi et al. 1988; Fine et al. 1989; Kletter at al. 1989). We have recently identified mutations in two of the hemidesmosome structural proteins in patients with these forms of EB. Following initial immunofluorescence analysis (Jonkman et al. 1995), we recently established that GABEB results from mutations in the BP180/COL17A1 gene in two unrelated families (McGrath et al. 1995, 1996). Similarly, absence of $\beta 4$ integrin (Gil et al. 1994) led to the discovery of mutations in the $\beta 4$ integrin gene (ITGB4) in a patient with EB-PA (Vidal et al. 1995). Although any of the other components of the hemidesmosome could serve as equally likely candidates for mutations in the MD-EBS group of patients, a recent report of a knockout mouse for BP230 (Guo et al. 1995) and the finding that the $d t$ mouse mutation is in the analogous murine gene for BP230 (Brown et al. 1994; 1995) have provided further insight into the functional role of the hemidesmosome inner plaque.

In this study we report cloning of human plectin cDNA and genomic sequences, and chromosomal mapping of the corresponding gene, PLEC1. We also demonstrate a homozygous 8-bp deletion in a patient with MDEBS, thus providing an explanation for the combined phenotypic manifestations of skin fragility and muscular dystrophy.

\section{Results \\ $M D-E B S$ phenotype: neonatal skin blistering with late-onset $M D$}

The proband is a 24-year old Hispanic male, who is the elder of two children of parents that are first cousins (Fig. 1). There is no prior history of skin fragility disorders or muscular dystrophy in the family. The proband was delivered after an uneventful pregnancy but developed blisters on the feet, back, thighs, and face at the age of 10 days, which continued to recur in sites of mechanical trauma. The blisters heal with atrophic scarring, and he has nail dystrophy and dental abnormalities (Fig. 1). Electron microscopy revealed poorly formed hemidesmosomes along the roof of the blister, with a portion of the hemidesmosome remaining attached to the base of the blister (Fig. 2). Tonofilaments within the basal cells were found to make no contact with these rudimentary hemidesmosomes, indicating that a failure of keratinhemidesmosome attachment might be the cause of skin fragility in this MD-EBS patient.

The proband's developmental milestones were normal until the tenth year of life, when his parents noticed that he was tiring easily, in that stair climbing became difficult and he stopped running. His upper limbs soon became involved and combing his hair was not possible. An electromyograph revealed a long-standing neuromuscular disease, and a muscle biopsy revealed that the muscle fibers had group atrophy. He was diagnosed with a 
Figure 1. Pedigree and clinical presentation of the patient with MD-EBS. The patient (III3 ) is indicated by an arrow. His unaffected parents (II-8 and II-9) were first cousins of Hispanic origin, and his younger sister (III-4) is clinically unaffected. Clinical features of the patient's skin: $\{A \mid$ Nail dystrophy, erosions, and hyperpigmented areas over the hands; $(B)$ a small fluid-filled blister on the inner aspect of the elbow.

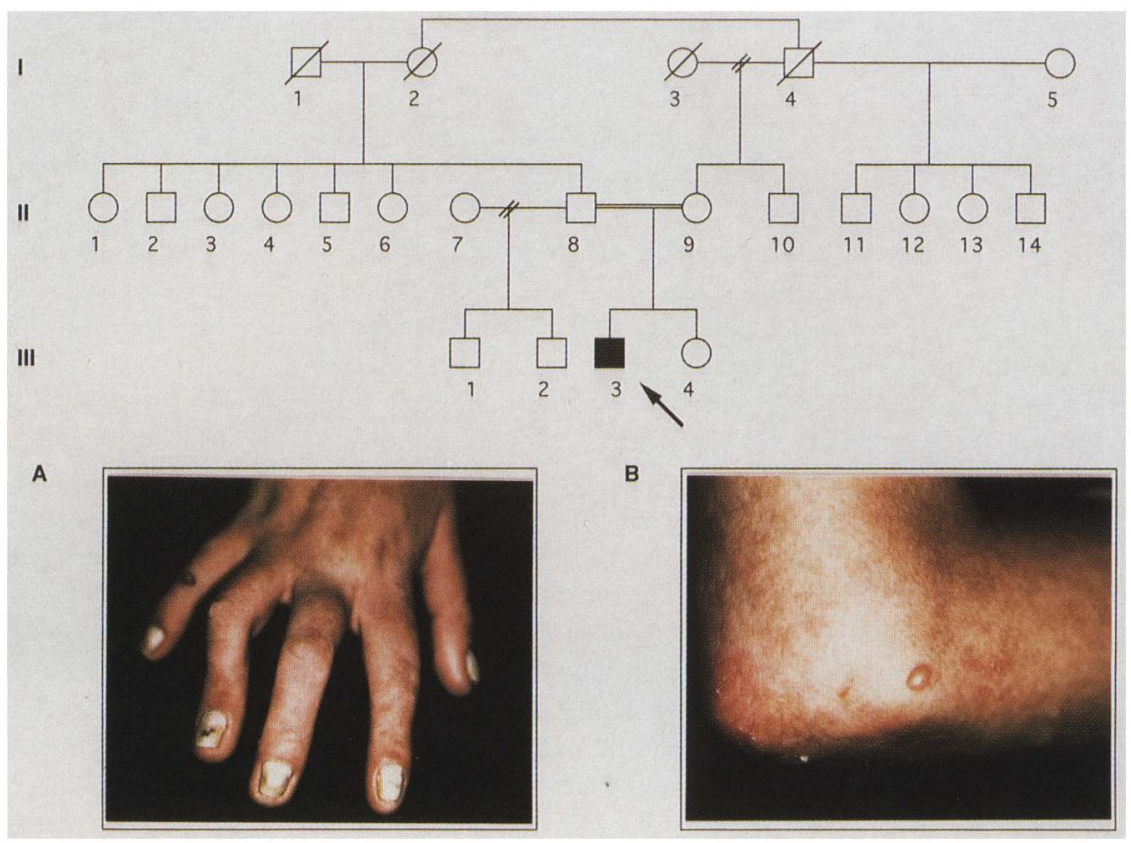

form of spinal muscular atrophy and by age 13 was permanently confined to a wheelchair. He has normal intelligence, has graduated from high school, and takes college courses. The clinical course of the proband in this study consists of EB presenting in infancy with a lateonset severe muscular degcneration.

\section{Plectin and HD1 expression is absent in MD-EBS skin and cultured keratinocytes}

Because electron microscopy had indicated a possible defect in keratin-hemidesmosome interaction, the expression of hemidesmosomal components was examined by immunofluorescence in skin biopsy specimens from the MD-EBS proband. In normal skin, bright linear staining was observed with monoclonal antibody $\mathrm{HD}$ / (Owaribe et al. 1991; Hieda et al. 1992) at the dermo-epidermal junction (Fig. 3A). In contrast, there was complete absence of staining in the skin of the MD-EBS patient (Fig. 3B). Because HDl was reported to be of a similar molecular weight to plectin (Owaribe et al. 1991; Wiche et al. 1991) and both proteins were known to localize to the dermo-epidermal interface region (Nagle et al. 1995), we postulated that HDl and plectin might be identical or related proteins and so plectin expression was investigated in the patient's skin. In normal epidermis, staining of the dermo-epidermal junction was observed with antiplectin mAb 7A8 (Foisner et al. 1994), similar to that seen with HDl (Fig. 3C), but in addition, cytoplasmic staining is also seen with $7 \mathrm{~A} 8$, as reported previously

Figure 2. Electron micrograph showing lowlevel intraepidermal blister formation in the skin of the MD-EBS patient. Thin filaments of basal keratinocytes including hemidesmosomes (open arrows) can be seen at the base of the incipient blister (asterisk), attached to the epidermal basement membrane (arrowheads), and separated from nucleated portions of the cells (E). (D) Dermis. Bar, $1 \mu \mathrm{m}$. (Inset) Detail of the hemidesmosome plaques (open arrows). Identifiable attachments to keratin intermediate filaments are absent. Bar, $0.5 \mu \mathrm{m}$.

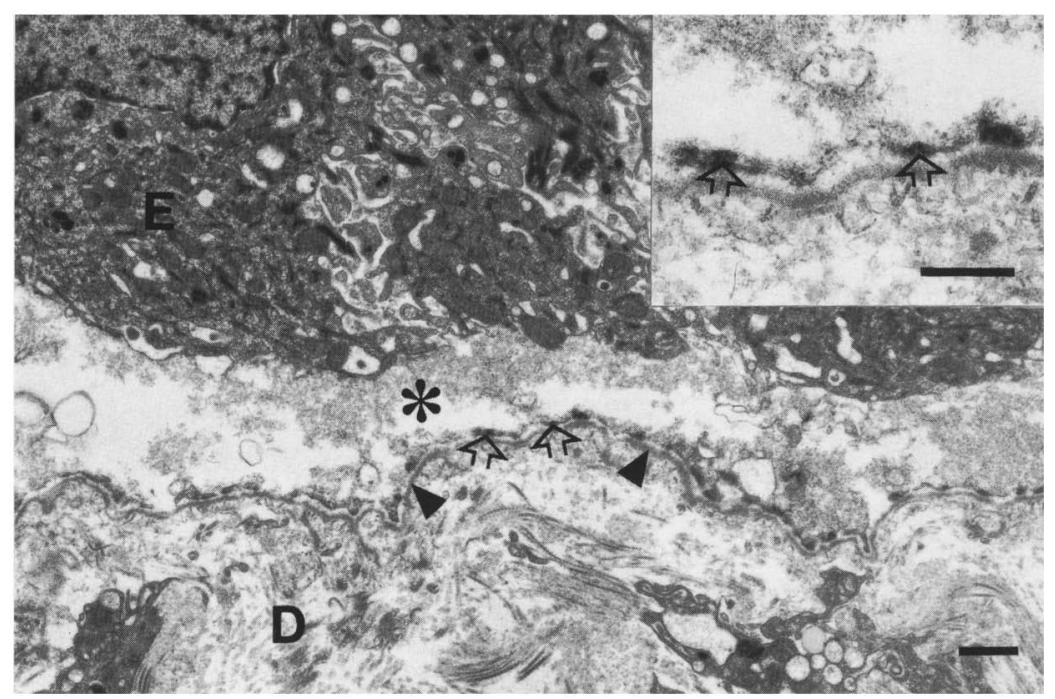



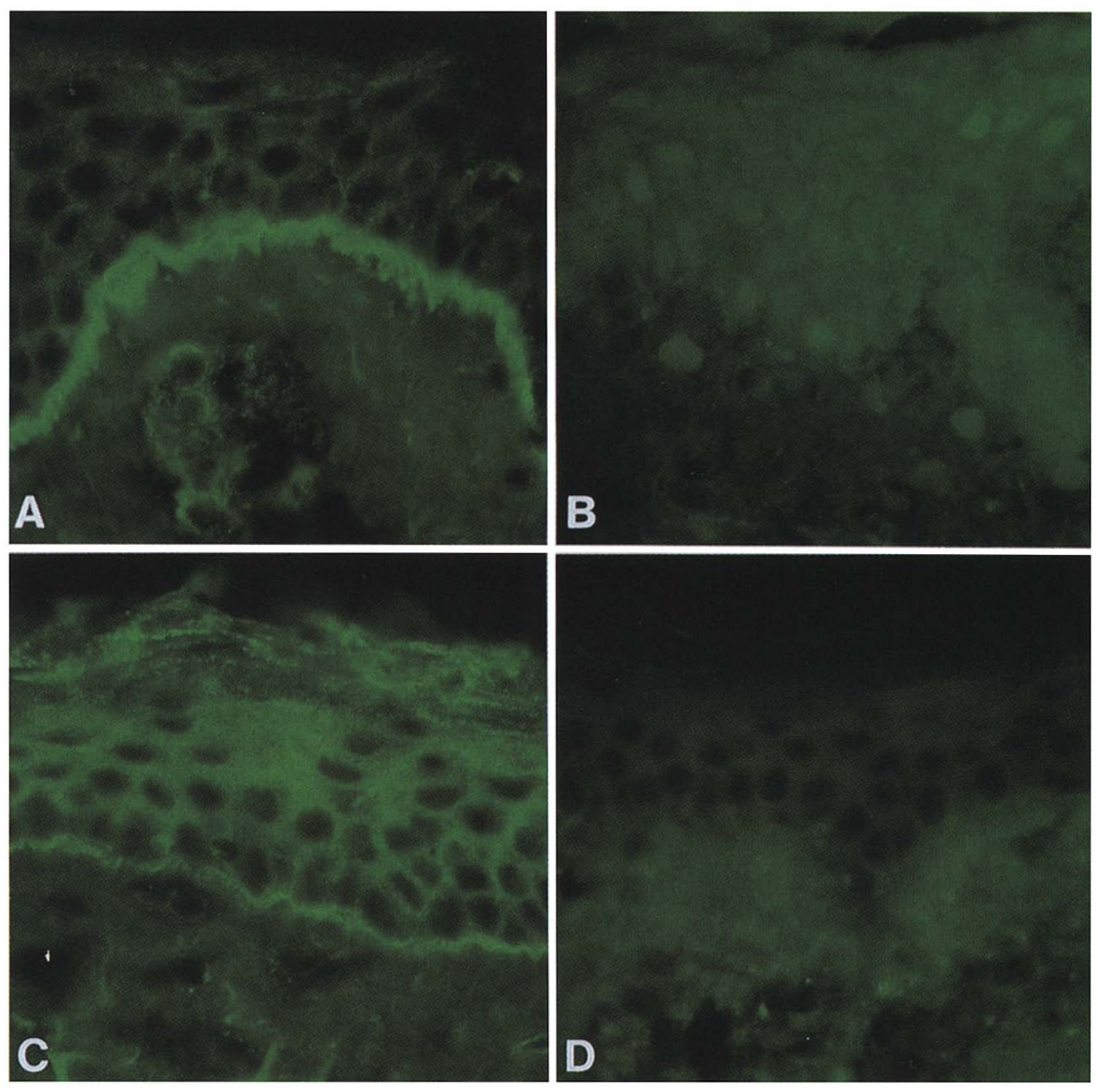

Figure 3. Indirect immunofluorescence staining of skin biopsy material using antibody against $\mathrm{HDl}$ and plectin. $(A, C)$ Cryosections from a normal individual; $(B, D)$ cryosections from the MD-EBS patient under study. Bright linear staining is seen in the region of the dermo-epidermal junction with antibody HD1 in normal skin $(A)$ but this staining is completely absent from the skin of the MD-EBS patient $(B)$. Similarly, the dermo-epidermal junction and cytoplasm of epidermal keratinocytes is stained with antiplectin $\mathrm{mAb} 7 \mathrm{~A} 8(C)$, but in contrast this staining is absent in MD-EBS skin $(D)$.
(Seifert et al. 1992; Foisner et al. 1994). However, 7A8 staining was found to be completely absent in the skin of the MD-EBS patient (Fig. 3D). Staining patterns obtained in skin sections from the patient using antibodies to other hemidesmosome antigens $\alpha 6$ and $\beta 4$ integrins and BP180 appeared normal, although BP230 staining was slightly attenuated (not shown).

The patient's keratinocyte cultures were established from skin biopsies with apparently normal efficiency and were negative by immunofluorescence with antibodies to plectin and HD1 (not shown). Because immunostaining may not identify antigens below a critical concentration, absence of the HD1 antigen was confirmed by immunoprecipitation of $\left[{ }^{35} \mathrm{~S}\right]$ methionine/cysteine-labeled keratinocyte extracts with anti-laminin 5 , anti-integrin $\alpha 6$, and anti-HD1 antibodies. The patterns for laminin 5 (data not shown) and integrin $\alpha 6$ were identical for both patient and control cells (Fig. 4). No immunoprecipitate was obtained from patient cells using the anti-HDl antibody while multiple bands were precipitated by anti-HD1 antibodies from control cells (Fig. 4). Similar results were obtained using anti-plectin $\mathrm{mAb}$ $7 \mathrm{~A} 8$, confirming that $\mathrm{HD} 1$ and plectin expression was absent in the patient (not shown). The reason for the presence of multiple bands in control cells is not clear, but they appear not to be attributable to degradation, as the profiles for laminin 5 (not shown) and integrin $\alpha 6$ (Fig. 4) precipitates consisted of distinct bands of the expected size.
Human plectin is encoded by a $14.8-\mathrm{kb} \mathrm{mRNA}$

On the basis of the immunofluorescence results (Fig. 3), we postulated that a molecular defect in the plectin gene

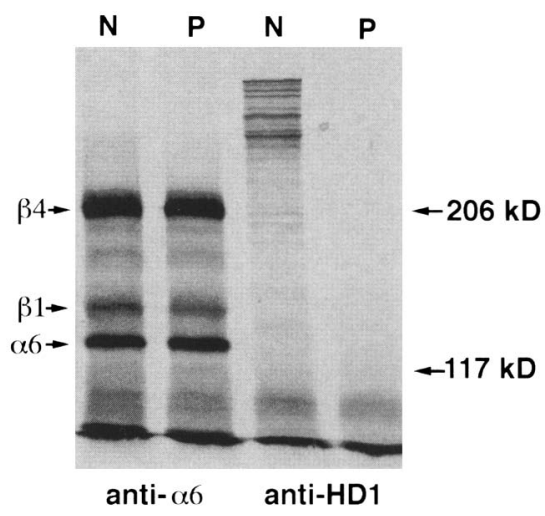

Figure 4. Normal $(\mathrm{N})$ and patient's $(\mathrm{P})$ keratinocytes were metabolically labeled with $\left[{ }^{35} \mathrm{~S} \mid \mathrm{methionine/cysteine.} \mathrm{Protein} \mathrm{ex-}\right.$ tracts of the cells were immunoprecipitated separately with anti-HD1 or anti- $\alpha 6$ integrin monoclonal antibodies, and equal amounts of radioactivity were applied to a $4 \%$ polyacrylamide gel. While both normal and patient's cells synthesized approximately equal amounts of integrins containing the $\alpha 6$ subunit ( $\alpha 6 \beta 4$ and $\alpha 6 \beta 1$, HD1 could be immunoprecipitated only from normal cells. Relative molecular masses shown at right were deduced from markers included in the gel (not shown). 

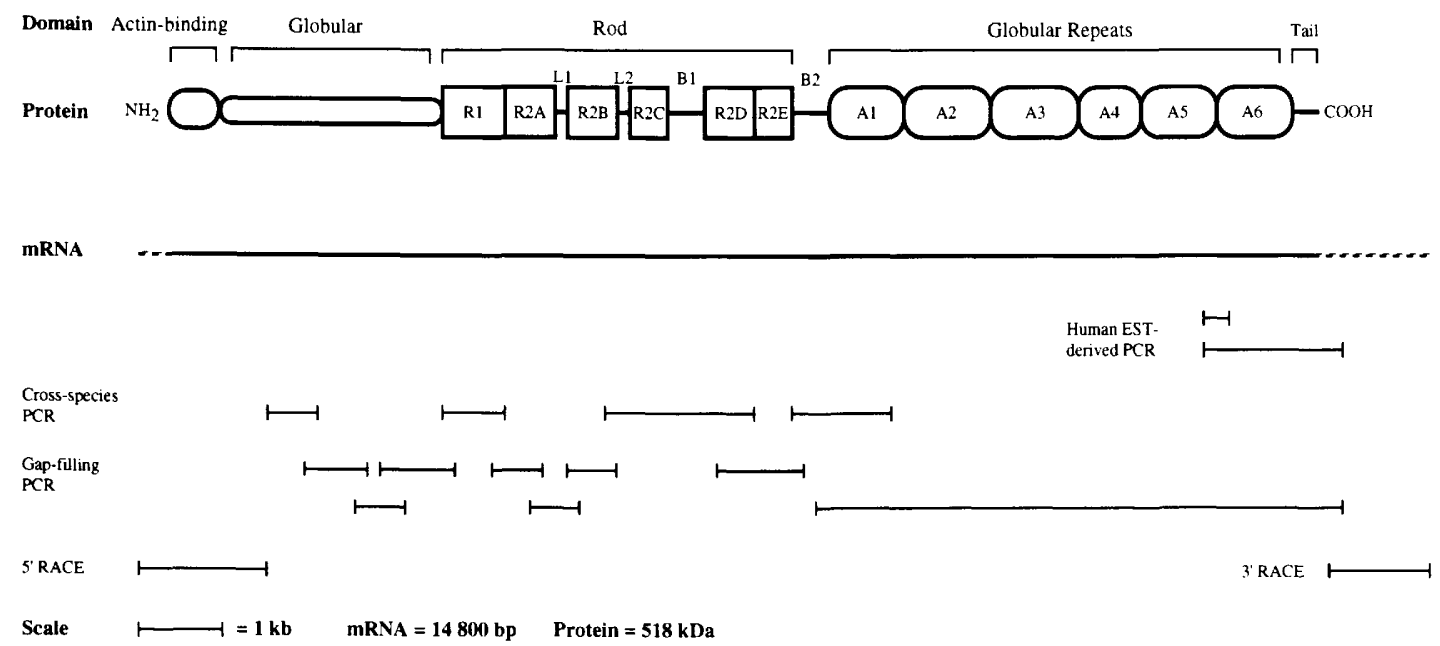

Figure 5. Cloning strategy used for the isolation and sequencing of the 14.8 -kb human plectin mRNA and schematic representation of the deduced $518-\mathrm{kD}$ protein. The domain designation as described for rat plectin (Wiche et al. 1991) is used, except at the amino terminus where additional sequences were found upstream of the putative initiation codon in the rat sequence. These additional sequences encode a domain with strong homology to the actin-binding domains of spectrin, actinin, and members of the dystrophin family (see Fig. 9). The protein consists of an amino-terminal actin-binding domain, globular domain, coiled-coil rod domain, and carboxy-terminal intermediate filament-binding domain.

might be the underlying cause of MD-EBS. A PCR-based cDNA cloning strategy was used to clone the entire 14.8$\mathrm{kb}$ plectin mRNA (GenBank accession no. U53204) from human primary keratinocytes as outlined in Figure 5. A number of human expressed sequence tags (ESTs) were identified by searching the EMBL data base with the rat mRNA sequence of Wiche et al. (1991). Two of these, HSL13357 [the most 3' EST, which contained sequences in the predicted $3^{\prime}$ untranslated region (UTR)] and HSXS165 (located $\sim 1 \mathrm{~kb} \mathrm{3}$ ' of the presumptive human translation termination codon), were used to design primers for reverse transcription (RT)-PCR (Fig. 5) using human keratinocyte mRNA as template. A 400-bp PCR fragment within the HSXS165 EST was amplified from genomic DNA without intronic sequences and was used for isolation of genomic P1 clones (below). A larger fragment generated between the two ESTs was found to contain an open reading frame (ORF), with a predicted translation of $>90 \%$, similar to rat plectin, and a termination codon and 3' UTR in the same position as the rat mRNA (Fig. 6). Primers in this region were used for $3^{\prime}$ RACE (rapid amplification of cDNA ends) PCR and led to identification of the polyadenylation signal and poly(A) tract (Fig. 6).

A series of cross-species PCR primers were designed across the rat mRNA and were used in combination with a long-range RT-PCR protocol developed using rat mRNA to generate four further sequence islands across the human mRNA, including the region close to the predicted initiation codon (Fig. 5). The gaps between these islands were closed by RT-PCR using human-specific primers. RACE PCR was used to isolate the $5^{\prime}$ end of plectin message, in combination with genomic sequencing. The ORF was found to continue upstream of the putative initiation codon in the homologous rat mRNA, and an out-of-frame ATG was detected in this region. Thus, the original assignment of the initiation codon in the rat mRNA appears not to be correct (Wiche et al. 1991). A series of $5^{\prime}$ RACE fragments extending $1.4 \mathrm{~kb}$ upstream of the putative ATG were generated and sequenced. The deduced amino acid sequence of the 518$\mathrm{kD}$ human plectin protein, consisting of 4574 amino acids is shown in Figure 6. One alternately spliced transcript was observed involving the exon 9-intron 9 junction, where an alternate $5^{\prime}$ splice was used, leading to a deletion of $12 \mathrm{bp}$ from exon 9 (Fig. 6).

\section{Plectin has a spectrin-like actin-binding domain}

The domain structure within the partial plectin sequence reported by Wiche et al. (1991) is well conserved between rat and human as shown in Figure 5. We identified additional sequences upstream of the initiation codon suggested previously for the rat mRNA, which extend the ORF within the message by $1.4 \mathrm{~kb}$. BLAST analysis (Altschul et al. 1990) of this additional sequence revealed high homology to the actin-binding domains of human $\beta$-spectrin, $\alpha$-actinin, utrophin, and dystrophin (Fig. 7). Plectin is therefore predicted to have an actinbinding domain situated at the amino terminus, analogous to spectrin, dystrophin, and related proteins. Downstream of the actin-binding domain, homology to spectrin continued into the first spectrin repeat motif. This motif is also observed in varying numbers in $\alpha$-actinin, utrophin, and dystrophin, but plectin only possesses one such sequence. Interestingly, the 12-bp deletion in the plectin splice variant observed (Fig. 6) leads to the deletion of 4 amino acids from this less well-conserved region, so that this alteration might not be functionally important. Outside the actin-binding domain, compari- 
(A)

Human plectin: predicted protein sequence

4574 amino acids, calculated molecular weight $517904 \mathrm{Da}$

MSGEDAEVRA VSEDVSNGSS GSPSPGDTLP WNLGKTQRSR RSGGGAGSNG SVLDPAERAV IRIADERDRV QKKTFTKWVN KHLIKAQRHI SDLYEDLRDG HNLISLLEVI SGDSLPREKG RMRFHKLQNV QIALDYLRHR QVKLVNIRDD DIADGNPKLT. LGLIWTIILH FQISDIQVSG QSEDMTAKER LILIWSQRMVE GYQGLRCDNF TSSWRDGRLF NAIIHRHKPL LIDMNKVYRQ TNLENIDQAF SVAERDLGVT RLLDPEDVDV PQPDEKSIIT YVSSLYDAMP RVPDVQDGVR ANELQLRWOE YRELVLLLLQ WMRHHTAAFE ERRFPSSFEE IEILWSOFLK FKEMELPAKE ADKNRSKGIY OSLEGAVQAG QLKVPPGYHP LDVEKEWGKL HVAILEREKQ LRSEFERLEC LQRTVTKLQM EAGLCEEQLN QADALLQSDV RLLAAGKVPQ RAGEVERDLD KADSMIRLLF NDVQTLKDGR HPQGEQMYRR VYRLHERLVA IRTEYNLRLK AGVAAPATOV AQVTLQSVQR RPELEDSTLR YLQDLIAWVE ENQHRVDGAE WGVDLPSVEA OLGSHRGLHQ SIEEFRAKIE RARSDEGQLS PATRGAYRDC LGRLDLOYAK LINSSKARTR SLFSLHSFVA AATKELMTLN EKEEEEVGFD WSDRNTNMTA KKESYSALMR ELELKEKKIK ELQNAGDRLL REDHPARPTV ESFOAALQTO WSWMLOLCCC IEAHLKENAA YFOFFSDVRE AEGOLQKLOE ALRRKYSCDR SATVTRLEDL LQDAQDEKEQ ELQNAGDRLL REDHPARPTV ESFQAALQTO WSWMLQLCCC IEAHLKENAA YFQFFSDVRE AEGQLQKLQE ALRRKYSCDR SATVTRLEDL LQDAQDEKEQ
LNEYKGHLSG LAKRAKAVVQ LKPRHPAHPM RGRLPLLAVC DYKQVEVTVH KGDECOLVGP AQPSHWKVLS SSGSEAAVPS VCFLVPPPNQ EAQEAVTRLE LNEYKGHLSG LAKRAKAVVQ LKPRHPAHPM RGRLPLLAVC DYKQVEVTVH KGDECQLVGP AQPSHWKVLS SSGSEAAVPS VCFLVPPPNQ EAQEAVTRLE
AQHQALVTLW HQLHVDMKSL LAWQSLRRDV OLIRSWSLAT FRTLKPEEQR QALHSLELHY QAFLRDSQDA GGFGPEDRLM AEREYGSCSH HYQQLLQSLE QGAQEESRCQ RCISELKDIR LQLEACETRT VHRLRLPLDK EPARECAQRI AEQQKAQAEV EGLGKGVARL SAEAEKVLAL PEPSPAAPTL RSELELTLGK J.EQVRSLSAI YLEKLKTISL VIRGTQGAEE VLRAHEEQLK EAQAVPATLP ELEATKASLK KLRAQAEAQQ PTFDALRDEL RGAQEVGERL QQRHGERDLE VERWRERVAQ VLERWQAVLA QTDLRQRELE QLGRQLRYYR ESADPLGAWL QDARRRQEQI QAMPLADSQA VREQLRQEQA LLEEIERHGE KVEECQRFAK QYINAIKDYE LQLVTYKAQL EPVASPAKKP KVQSGSESVI QEYVDLRTHY SELTTLTSQY IKFISETLRR MEEEERLAEQ QRAEERERLA EVEAALEKQR QLAEAHAQAK AQAEREAKEL QQRMQEEVVR REEAAVDAQQ QKRSIQEELQ QLRQSSEAEI QAKARQAEAA ERSRLRIEEE IRVVRLQLEA TERQRGGAEG ELQALRARAE EAEAQKRQAO EEAERLRRQV QDESORKRQA EVELASRVKA ETEAAREKQR ALQALEELRL QAEEAERRLR QAEVERARQV QVALETAQRS AEAELQSKRA SFAEKTAQLE RSLOEEHVAV AOLREEAERR AQOQAEAERA RFEAERELER WOLKANEALR LRLQAEEVAO OKSLAQAEAE KQKEEAEREA AEAELQSKRA SFAEKTAQLE RSLQEEHVAV AQLREEAERR AQQQAEAERA REEAERELER WQLKANEALR LRLQAEEVAQ QKSLAQAEAE KQKEEAEREA
RRRGKAEEQA VRQRELAEQE LEKQRQLAEG TAQQRLAAEO ELIRLRAETE OGEQQRQLLE EELARLQREA AAATQKRQEL EAELAKVRAE MEVLLASKAR RRRGKAEEQA VRQRELAEQE LEKQRQLAEG TAQQRLAAEQ ELIRLRAETE QGEQQRQLLE EELARLQREA AAATQKRQEL EAELAKVRAE MEVLLASKAR
AEEESRSTSE KSKORLEAEA GRFRELAEEA ARLRALAEEA KROROLAEED AARORAEAER VLAEKLAAIG EATRLKTEAE IALKEKEAEN ERLRRLAEDE AEEESRSTSE KSKQRLEAEA GRFRELAEEA ARLRALAEEA KRQRQLAEED AARQRAEAER VLAEKLAAIG EATRLKTEAE IALKEKEAEN ERLRRLAEDE
AFORRRLEEO AAOHKADIEE RLAOLRKASD SELFRQKGLV EDTLRQRROV EEETLALKAS FEKAAAGKAE LELELGRIRS NAEDTLRSKE CAELEAAROR AFQRRRLEEQ AAQHKADIEE RLAQLRKASD SELERQKGLV EDTLRQRRQV EEEILALKAS FEKAAAGKAE LELELGRIRS NAEDTLRSKE QAELEAARQR QLAAEEERRR REAEERVQKS LAAEEEAARQ RKAALEEVER LKANVEEARR LRERAEQESA RQLQLAQEAA QKRLQAEEKA HAFAVQQKEQ ELQQTLQQEQ SVLDQLRGEA EAARRAAEEA EEARVQAERE AAQARRQVEE AERLKQSAEE QAQARAQAQA AAEKLRKEAE QEAARRAQAE QAALRQKQAA DAEMEKHKKF AEQTLRQKAQ VEQELTTLRL QLEETDHQKN LLDEELQRLK AEATEAARQR SQVEEELFSV RVQMEELSKL KARIEAENRA LILRDKDNTQ RFLQEEAEKM KQVAEEAARL SVAAQEAARL RQLAEEDLAQ QRALAEKMLK EKMQAVQEAT RLKAEAELLQ QQKELAQEQA RRLQEDKEQM AQQLAEETQG FQRTLEAERQ RQLEMSAEAE RLKLRVAEMS RAQARAEEDA ORERKQAEEI GEKLHRTELA TQEKVTLVQT LEIQRQQSDH DAERLREAIA ELEREKEKIQ QEAKLLQLKS EEMQTVQQEQ LLQETQALQQ SFLSEKDSLL ORERFIEOEK AKLEOLFODE VAKAQQLREE OQRQOOOMEO ERORLVASME EARRRQHEAE EGVRRQEEL QQLEQQRRQQ EELLAEENQR LREQLQLLEE QHRAALAHSE EVTASQVAAT KTLPNGRDAL DGPAAEAEPE HSFDGLRRKV SAQRLQEAGI LSAEELQRLA QGHTTVDELA RREDVRHYLQ GRSSIAGLLL KATNEKLSVY AALQRQLLSP GTALILLEAQ AASGFLLDPV RNRRLTVNEA VKEGVVGPEL HHKLLSAERA VTGYKDPYTG QQISLFQAMQ KGLIVREHGI RLLEAQIATG GVIDPVHSHR VPVDVAYRRG YFDEEMNRVL ADPSDDTKGF FDPNTHENLT YLQLLERCVE DPETGLCLLP LTDKAAEGGE LVYTDSEARD VFEKATVSAP FGKFOGKTVT IWEITNSEYF TAEQRRDLLR QFRTGRITVE KIIKIIITVV EEQEQKGRLC FEGLRSLVPA AELLESRVID RELYQQLQRG ERSVRDVAEV DTVRRALRGA NVIAGVWLEE AGQKLSIYNA LKKDLLPSDM AVALLEAQAG TGHIIDPATS ARLTVDEAVR AGLVGPEFHE KLLSAEKAVT GYRDPYTGQS VSLFOALKKG LIPREOGLRL LDAQLSTGGI VDPSKSHRVP LDVACARGCL DEETSRALSA PRADAKAYSD PSTGEPATYG ELQQRCRPDQ LTGLSLLPLS EKAARARQEE LYSELQARET FEKTPVEVPV GGFKGRTVTV WELISSEYFT AEQRQELLRQ FRTGKVTVEK VIKILITIVE EVETLROERL SFSGLRAPVP ASELLASGV SRAOFEOLKD GKTTVKDLSE LGSVRTLLOG SGCLAGIYLE DTKEKVSIYE AMRRGLRAT TAALLLEAOA ATGFLVDPVR NQRLYVHEAV KAGVVGPELL EOLLSAEKAV TGYRDPYSGS TISLFQAMQK GLVLRQHGIR LLEAQIATGG IIDPVHSHRV PVDVAYQRGY FSEEMNRVLA DPSDDTKGFF DPNTHENLTY RQLIERCVED PETGLRLLPL KGAEKAEVVE TTQVYTEEET RRAFEETQID IIDPVHSHRV PVDVAYQRGY FSEEMNRVLA DPSDDTKGFF DPNTHENLTY RQLIERCVED PETGLRLLPL KGAEKAEVVE TTQVYTEEET RRAFEETQID
IPGGGSHGGS TMSLWEVMQS DLIPEEQRAQ LMADFQAGRV TKERMIIIII EIIEKTEIIR QQGLASYDYV RRRLTAEDLF EARIISLETY NLLREGTRSL IPGGGSHGGS TMSLWEVMQS DLIPEEQRAQ LMADFQAGR TKERMIIIII EIIEKTEIIR QQGLASYDYV RRRLTAEDLF EARIISLETY NLLREGTRSL PYTEQTISLF QAMKKELIPT EEALRLLDAQ LATGGIVDPR LGFHLPLEVA YQRGYLNKDT HDQLSEPSEV RSYVDPSTDE RLSYTQLLRR CRRDDGTGQL LLPLSDARKL TFRGLRKQIT MEELVRSQVM DEATALQLRE GLTSIEEVTK NLOKFLEGTS CIAGVVVDAT KERLSVYQAM KKGIIRPGTA FELIEAQAAT GYVIDPIKGL KLTVEEAVRM GIVGPEFKDK LLSAERAVTG YKDPYSGKLI SLFOAMKKGL ILKDHGIRLI EAQIATGGII DPEESHRLPV EVAYKRGLFD EEMNEILTDP SDDTKGFFDP NTEENLTYLO LMERCITDPQ TGLCLLPLKE KKRERKTSSK SSVRKRRVVI VDPETGKEMS VYEAYRKGLI DHOTYLELSE OECENEEITI SSSDGWKSM IIDRRSGRQY DIDDATAKNT TEETGPVAGI LDTETLEKVS ITEAMHRNLV DNITGORLE AQACTGGITD PSTGERFPVT DAVNKGLVDK IMVDRTNLAO KAFCGFFDPR TKTKMSAAOA LKKGWLYYEA GQRFLEVQYL TGGLIEPDTP GRVPLDEALQ RGTVDARTAQ KLRDVGAYSK YLTCPKTKIK ISYKDALDRS MVEEGTGLRL LEAAAQSTKG LKKGWLYYA GQRFLEVQYL TGGLIEPDTP GRVPLDEALQ RGTVDARTAQ KLRDVGAYSK YLTCPKTKLK ISYKDAL

(B)

5 .

5. UTR

1 cgccegggca ggtggcggca gagctgaagt gagcggagec accaggaggC CATGTCGGGT GAGGAC...

$\begin{array}{lllll}M & S & G & E & D\end{array}$

(c)

3. flanking gequences

3' UTR

S A V A *

... gcggta tccgcccca ataaaaagcaa ttccaacctt

14800

(D) Splice variant

Exon 9

3001 ....GATGGG GTGAGGGCAAC gtgagtggggggccc...

Figure 6. (A) The predicted sequence of 4574 amino acids comprising human plectin as deduced from the single ORF within the 14.8-kb mRNA (GenBank accession no. U53204). The calculated molecular mass is 51,7904 daltons. (B) The sequence at the 5 ' end of the mRNA as determined by $5^{\prime}$ RACE consists of a 51-bp UTR that contains an in-frame stop codon, indicating that this is a genuine UTR. $(C)$ The 3' end of the mRNA as determined by 3' RACE consists of a 1026-bp UTR downstream of the TGA codon. Transcription was found to terminate $14 \mathrm{bp}$ downstream of a canonical polyadenylation signal. $(D)$ One alternative transcript was detected in the course of cDNA cloning. Four amino acids (VRAN) are removed by splicing to an alternate $5^{\prime}$ acceptor site 12 bp upstream of the exon 9 -intron 9 border. These transcripts were present in approximately equal amounts in primary keratinocyte cDNA. Base numbers in $B$ and $C$ refer to the mRNA sequence; those in $D$ refer to the genomic sequence.

son of rat and human sequences was possible. The overall protein sequence identity was found to be $86 \%$, with a similarity value of $91 \%$, taking into account conservative amino acid substitutions.

The human plectin gene maps to $8 q 24$

A short genomic PCR marker located within the HSXS165 region was used to isolate three human P1 ge- nomic clones (designated 9108-9110), each with an insert of $\sim 100 \mathrm{~kb}$. PCR analysis revealed that all three clones contained sequences from both $5^{\prime}$ and $3^{\prime}$ ends of the plectin gene. Clone 9109 was used for all genomic sequencing. Direct sequencing was carried out with several cDNA primers to obtain intron-exon borders. Longrange PCR was found to be highly efficient and specific using P1 DNA as template, and consequently, a series of 


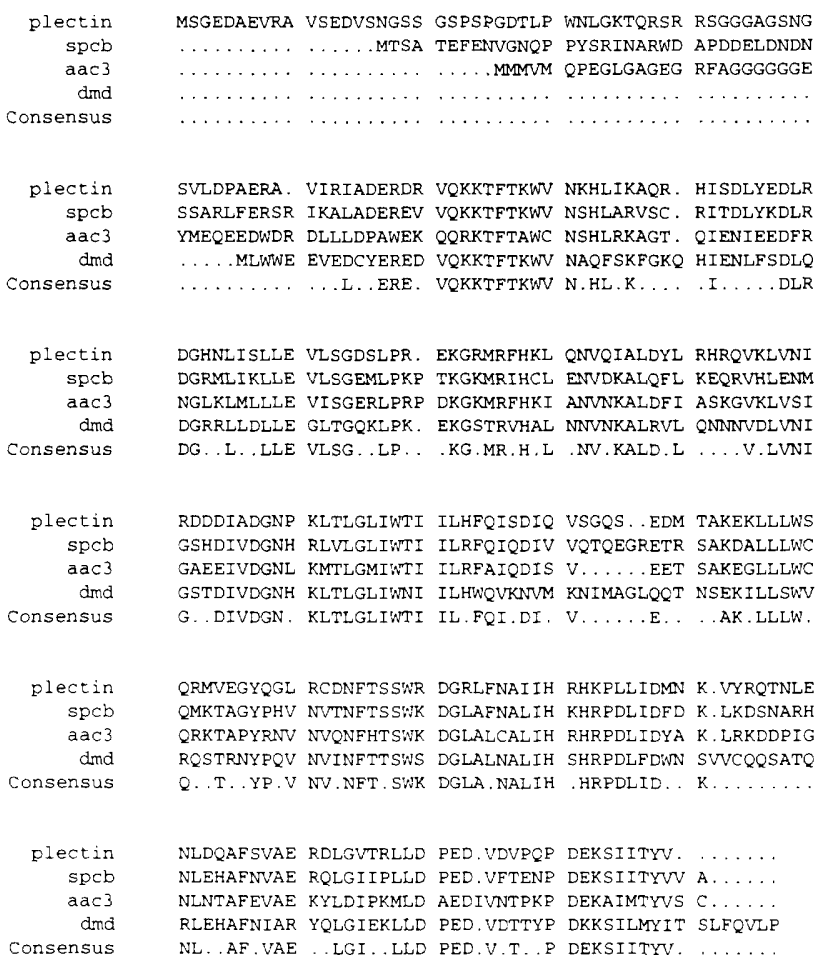
MMMNM QPEGLGAGEG RFAGGGGGGE
$\ldots \ldots$
$\ldots \ldots \ldots \ldots$

SVLDPAERA, VIRIADERDR VOKKTFTKWV NKHLIKAOR. HISDLYEDLR SSARLFERSR IKALADEREV VQKKTFTKWV NSHLARVSC. RITDLYKDLR YMEQEEDWDR DLLLDPAWEK QQRKTFTAWC NSHLRKAGT. QIENIEEDFR MLWWE EVEDCYERED VQKKTFTKWV NAQFSKFGKQ HIENLFSDLQ ........... . ERE. VQKKTFTKWV N.HL.K... .I. . . DLR

DGHNLISLLE VLSGDSLPR. EKGRMRFHKL QNVQIALDYL RHRQVKLVNI DGRMLIKLLE VLSGEMLPKP TKGKMRIHCL ENVDKALOFL KEQRVHLENM DGR IKLLE VLSGEMLPKE TKGKMRTHCL ENDKALOEL KEQRVHLENM NGLKLMLLE VISGERLPRP DKGKMRFHKI ANVNALDPI ASKGVKLVSI DGRRLLDLLE GLTGQKLPK. EKGSTRVHAL NNVNKALRVL QNNNVDLVNI DG. I. . LLE VLSG..LP. . .KG.MR.H.L .NV.KALD.L ...V.LVNI

RDDDIADGNP KLTLGLIWTI ILHFQISDIQ VSGQS. .EDM TAKEKLLLWS GSHDIVDGNH RLVLGLIWTI ILRFQIQDIV VQTQEGRETR SAKDALLLWC GAEEIVDGNL KMTLGMIWTI ILRFAIQDIS V......EET SAKEGLLLWC GSTDTVDGNH KLTLGLIMII ITHWQUKMTM KNTMAGLQQT NSEKILLSWV GSTDIVDGN KLTLCLIMT ILHWQVRTM KNIMACLQQ NSEKILLSW

QRMVEGYQGL RCDNFTSSWR DGRLFNAIIH RHKPLLIDMN K.VYRQTNLE QMKTAGYPHV NVTNFTSSWK DGLAFNALIH KHRPDLIDFD K.LKDSNARH QRKTAPYRNV NVQNFHTSWK DGLALCALIH RHRPDLIDYA K.LRKDDPIG RQSTRNYPQV NVINFTTSWS DGLALNALIH SHRPDLFDWN SWVCQQSATQ Q..T. YP V NV NFT SWK DGIA NALIH HRPDIID . K . .

NLDQAFSVAE RDLGVTRLED PED. VDVPCP DEKSIITYV. NLEHAFNVAE RQLGIIPLID PED.VFTENP DEKSIITYVN A....... NLNTAFEVAE KYLDIPKMLD AEDIVNTPKP DEKAIMTYVS C... RLEHAFNIAR YQLGIEKLLD PED.VDTTYP DKKSILMYIT SLFQVLP NL . AF. VAE . LGI . LLLD PED.V.T . P DEKSIITYV .

large genomic PCR fragments were generated and sequenced. The genomic organization of the human plectin gene, designated PLEC1 (GenBank accession no. U53834), is shown in Figure 8. A TATA-like sequence was found $29 \mathrm{bp}$ upstream of the $5^{\prime}$ end of the mRNA as determined from 5 ' RACE, thus confirming that this is likely to be the transcription initiation site. Similarly, the 3 ' extent of the mRNA ends 14 bp downstream of a polyadenylation signal. The gene is contained in $\sim 26 \mathrm{~kb}$ of genomic DNA in 33 exons, 2 of which are unusually large (Fig. 8). P1 DNA from clone 9109 was used for fluorescence in situ hybridization (FISH) analysis and gave a strong fluorescence signal with negligible background staining. By this means, the plectin locus was sublocalized to the telomere of the long arm of chromosome 8 , corresponding to band $8 \mathrm{q} 24$ as shown in Figure 9 .

Homozygous frameshift mutation in the plectin $m R N A$ in $M D-E B S$

The entire plectin coding sequence was amplified by RT-PCR from mRNA derived from epidermal keratinocytes of the affected individual, in similar fragments to those generated for the original cDNA strategy (Fig. 5), and were directly sequenced. The MD-EBS patient was found to be homozygous for three intragenic polymorphisms, whereas the unaffected parents and sibling were heterozygous (data not shown). A homozygous deletion of $8 \mathrm{bp}$ (5148del8; mRNA sequence, GenBank accession no. U53204) in exon 32 of the plectin gene was detected in the patient's cDNA (Fig. 10). This mutation leads to a premature TGA termination codon 42 bp downstream and predicts termination of protein translation within the R2B subdomain. Using a genomic PCR in the region, both parents were found to be heterozygous for this $\mathrm{mu}$ tation, as was the unaffected younger sibling, consistent with the linkage data. This mutation does not alter any known restriction site, but the deletion was excluded

Figure 7. Alignment of the putative amino-terminal actinbinding domain of plectin with the analogous domains of $\beta$-spectrin (spcb), $\alpha$-actinin 3 (aac3), and dystrophin (dmd). search using the amino-terminal 500 amino acids human plectin revealed a high degree of homology to the aminoterminal actin-binding domains of spectrin, actinin, dystrophin, utrophin, and related proteins. The actin-binding domain was designated as residues $1-282$ on the basis of homology to $\beta$-spectrin, to which plectin is most closely related. The consensus sequence shows only residues found in three or more of the proteins in the alignment.
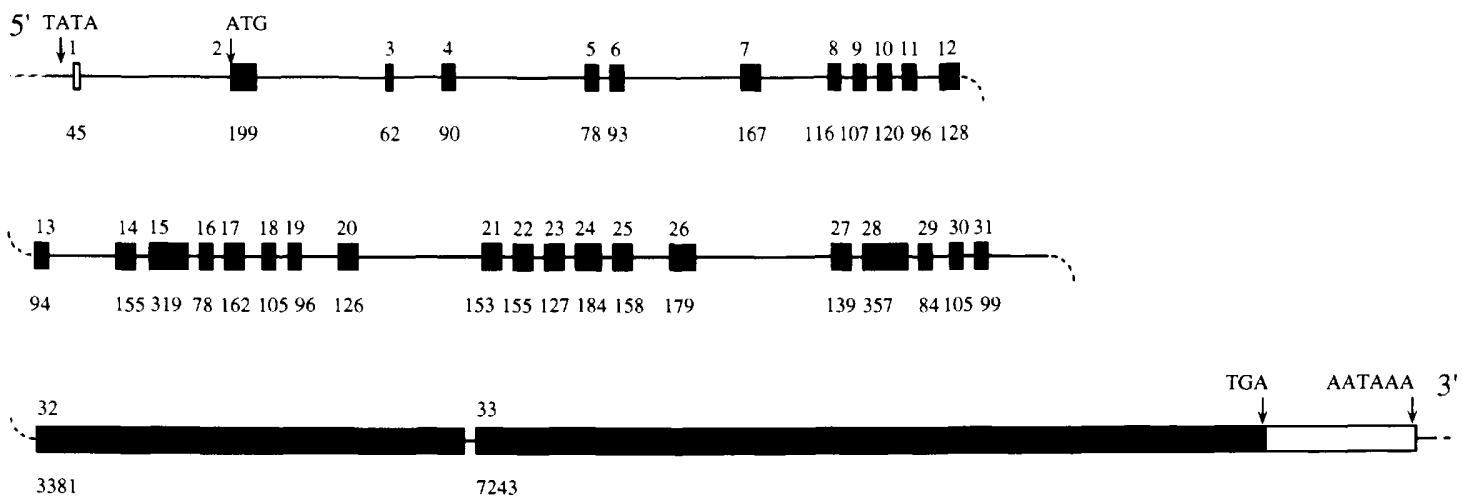

Scale: $\longmapsto=500 \mathrm{bp}$

Figure 8. Organization of the human plectin gene (PLECl) (GenBank accession no. U53834). The gene spans $>26 \mathrm{~kb}$ of genomic DNA and consists of 33 exons. The gene is quite compact for the expression of a $14.8-\mathrm{kb}$ mRNA, mainly because of the unusually large size of exons 32 amd 33 . 


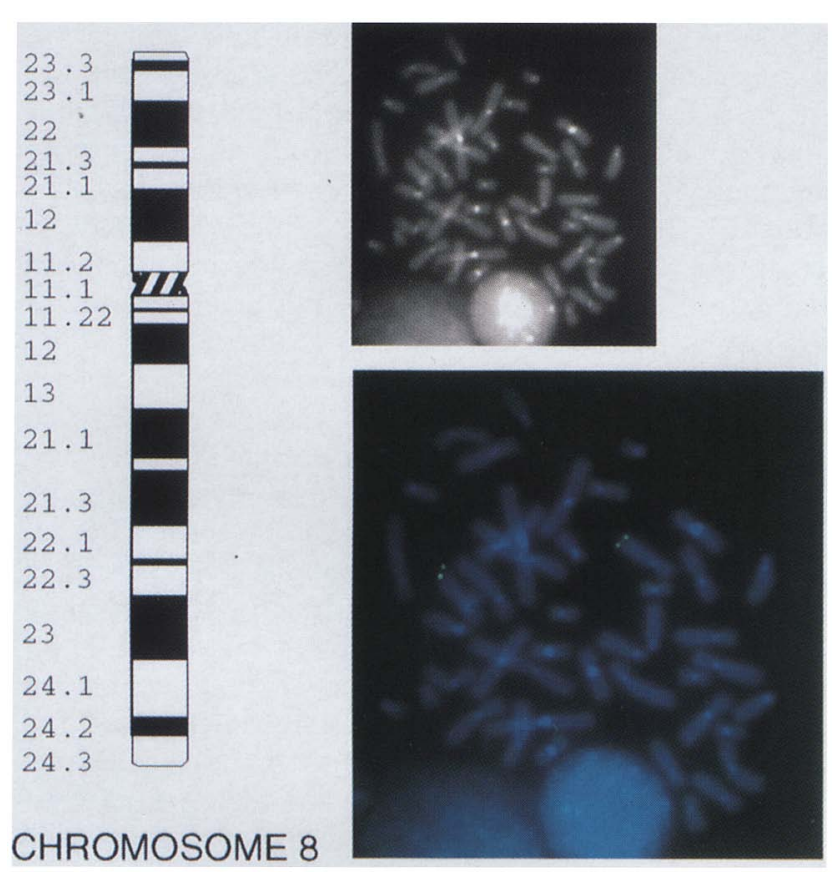

Figure 9. Physical localization of the plectin (PLECl) gene. FISH analysis with P1 clone 9109 on normal human metaphases shows hybridization to human chromosome 8 at band q24. (Left) Chromosome 8 idiogram showing major bands. (Right) Corresponding images of the same metaphase. (Top right) DAPIstained chromosomes; (bottom right) Pl hybridization signal close to the chromosome 8 telomere.

from 20 normal unrelated individuals by sequencing of genomic PCR products (not shown). The mutation occurred in a sequence where the 8-bp segment GGCGCGGC is tandemly repeated, suggesting a slipped mispairing mechanism of deletion (Krawczak and Cooper 1991).

\section{Discussion}

\section{Loss of plectin expression leads to $M D-E B S$}

Plectin is a member of a group of structurally and immunologically related intermediate filament-associated proteins, which includes BP230, desmoplakin, and IFAP300 (Wiche et al. 1991; Green et al. 1992; Skalli et al. 1994). These high molecular weight proteins are thought to share similar functions in that they are involved in the anchorage of cytoskeleton to transmembrane complexes. Plectin is also found in muscle, where it associates with the sarcolemma, and is a component of the hemidesmosome in basal keratinocytes (Errante et al. 1994; Nagle et al. 1995).

In this paper we report the sequence of the human plectin mRNA and the plectin gene (PLEC1) and show that a homozygous premature termination codon mutation in the plectin gene leads to the MD-EBS phenotype through loss of plectin protein expression. The mutation is predicted to truncate the protein in the central rod domain so that the putative intermediate filament-bind- ing domain at the carboxyl terminus is lost completely. This premature stop codon is likely to destabilize the 14.8 -kb plectin mRNA so that even the truncated translation product may be undetectable /Cooper 1993; Cui et al. 1995). This suggests that the patient in this study represents a natural knockout and indicates that plectin plays a critical role in maintenance of the structural in tegrity of the basement membrane zone in the skin. We also show that plectin has an amino-terminal actin-binding domain that is highly homologous to spectrin and $\alpha$-actinin, placing this protein in the dystrophin family of proteins, which are involved in the linkage of the muscle cytoskeleton to the sarcolemma, consistent with the myopathic aspect of the MD-EBS phenotype.

\section{A frameshift in the plectin gene leads to loss of HD1}

Given that plectin and the HD1 molecule are of very similar molecular weight /Owaribe et al. 1991; Wiche et

A
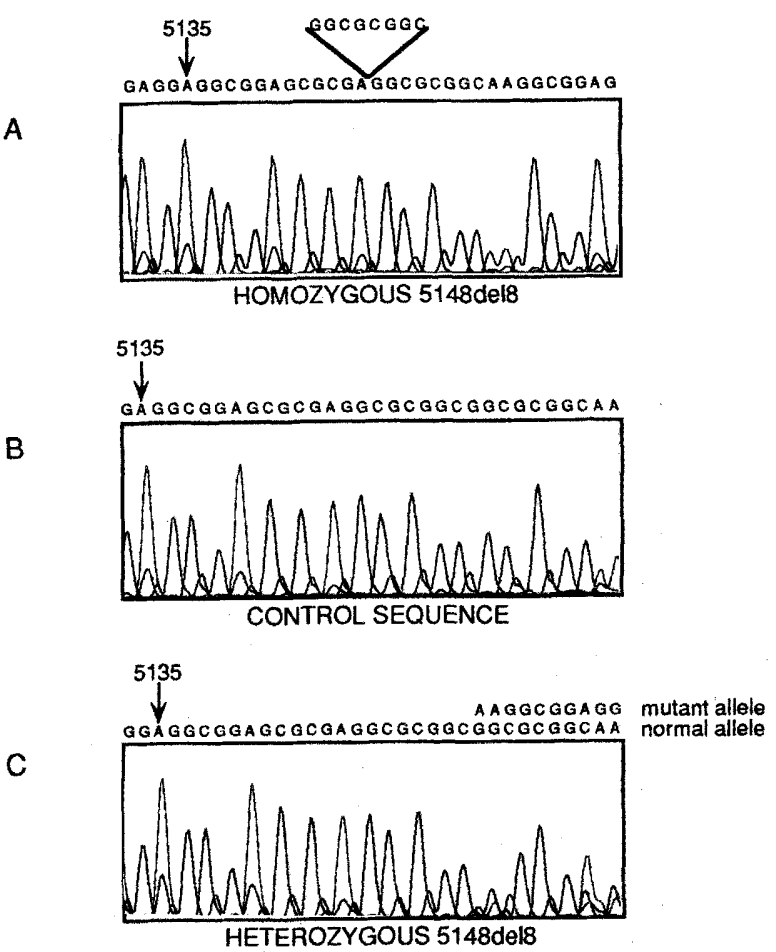

Figure 10. Homozygous frameshift mutation in the MD-EBS patient (individual III-3, Fig. 1). $\{A\}$ Direct sequencing of RTPCR-amplified fragment of plectin mRNA derived from the patient's cultured keratinocytes shows a homozygous 8-bp deletion mutation, designated 5148del8 (numbers refer to the mRNA sequence, GenBank accession no. U53204). The mutation is the excision of a repeat sequence GGCGCGGC, which occurs twice in the normal sequence. $(B)$ Direct sequencing of the analogous RT-PCR fragment amplified from keratinocyte mRNA derived from a normal individual. $(C)$ Direct sequencing of the analogous PCR fragment amplified from genomic DNA obtained from the carrier father of the proband (individual II-8, Fig. 1) produces overlapping sequences following base number 5148 , showing that this individual is heterozygous for the deletion mutation. A similar result was obtained for the clinically unaffected mother and sister of the proband (not shown). 
al. 1991), the complete absence of HDl (Owaribe et al. 1991) and plectin immunoreactivity (mAb 7A8; Foisner et al. 1994) in the MD-EBS patient suggests that these antigens might be one and the same. However, the staining patterns observed here with the two antibodies HDl and $7 \mathrm{~A} 8$ are clearly different (Fig. 3 ; see also Hieda et al. 1992; Seifert et al. 1992), although both stain the dermoepidermal junction. It is also possible that HDl is a different $500-\mathrm{kD}$ antigen to plectin but one with expression or assembly in the hemidesmosome complex that is dependent on plectin. Alternatively, HD1 and 7A8 might recognize distinct epitopes on the plectin molecule and that the HDl epitope is conformation dependent, exposed only when plectin interacts with other hemidesmosomal components; or the HD1 epitope could be specific to an alternatively spliced or post-translationally modified form of plectin that is involved only in hemidesmosome interactions.

PROSITE analysis of the plectin polypeptide revealed a large number of potential modification sites (not shown), and evidence for one alternative transcript was also noted during the cloning and sequencing of plectin (Fig. 6). Furthermore, multiple bands were observed in the immunoprecipitation experiments using HDl (Fig. 4), and similar results were obtained with immunoprecipitation experiments using $\mathrm{mAb} 7 \mathrm{~A} 8$. The observations are consistent with the existence of different isoforms of plectin, although there might be high molecular weight proteins that coprecipitate with plectin. Further analysis of these bands by peptide mapping or immunoblotting experiments with further plectin antibodies and production of specific antibodies against the peptides encoded by the splice variants is required to clarify whether HDl is a specific plectin epitope or represents a different gene product.

\section{Plectin contributes to epidermal and muscle integrity}

The carboxy-terminal domain of plectin has sequence homology to the intermediate filament-binding domains of desmoplakin and BP230 and has been shown experimentally to be involved in intermediate filament interaction (Wiche et al. 1993). The loss of plectin from the hemidesmosomes in MD-EBS correlates well with the skin fragility aspect of the disorder, as the level of blistering is within the basal cell compartment of the epidermis in the region where the keratin $\mathrm{K} 5 / \mathrm{K} 14$ filament network makes contact with the hemidesmosome (Fig. 2). Recently, the molecular basis of two other subtypes of EB have been uncovered where epidermal fragility is caused by the failure of other hemidesmosome components. These have been classified as GABEB, because of mutations in the BP180 gene (McGrath et al. 1995, 1996), and EB-PA caused by mutations in the gene encoding integrin $\beta 4$ (Vidal et al. 1995).

Ablation of the hemidesmosomal inner plaque protein BP230 in mice produces a phenotype of skin fragility and neuromuscular disease (Brown et al. 1994, 1995; Guo et al. 1995). Like those seen in the MD-EBS patient here
(Fig. 2), the hemidesmosomes in these mice lacked the inner plaque and demonstrated a complete separation of the hemidesmosomes from the intermediate filament network. Interestingly, other known hemidesmosome components, including HD1 and $\beta 4$ integrin, appeared undisturbed by the ablation of BP230, suggesting that the remaining hemidesmosome components are unable to maintain the interaction with the intermediate filament network. Taken with the findings reported here, it appears that although BP230 and plectin are reported to bind intermediate filaments, both proteins are required for correct hemidesmosome-keratin attachment.

The sequence similarity of plectin to dystrophin and related actin-binding proteins (Fig. 7), the muscle degeneration produced through ablation of plectin as described here, and immunolocalization of plectin to the sarcolemma (Foisner et al. 1994) point to an essential role for plectin in normal muscle function. The exact nature of this role is uncertain, but it is possible that plectin is involved in the connection of the actin and/or intermediate filament cytoskeletal systems of muscle to the sarcolemma, in a manner analogous to the model proposed for dystrophin (Campbell 1995). In epidermis, the essential function of plectin appears to be that of connecting the K5/K14 cytoskeleton to the hemidesmosome, and it seems likely that this multifunctional protein is performing a similar role in muscle. However, it is unclear as to whether it is (1) loss of intermediate filamentmembrane connection (perhaps desmin-membrane interaction), or (2) actin-membrane connection (similar to dystrophin), which leads to muscle fiber fragility and MD in MD-EBS. Further ultrastructural analysis of plectin expression in muscle by means of immunoelectron microscopy and biochemical analysis of the interaction of plectin with components of the muscle cytoskeleton and sarcolemma is essential to clarify how loss of plectin leads to MD in humans.

\section{Materials and methods}

Clinical material and diagnosis

A diagnostic skin biopsy from the proband at 16 years of age was performed at the National EB Registry Northeast Clinical Site at the Rockefeller University Hospital (New York, NY). Karyotype analysis revealed no chromosomal abnormalities. Subsequently, as part of this study, skin biopsies were obtained from the proband and the family members for cell culture. DNA was isolated from peripheral blood samples from the proband, his sister, and both parents by standard techniques.

\section{Keratinocyte cultures}

Normal human keratinocytes were isolated from neonatal foreskin as described previously (Marinkovich et al. 1993), and keratinocytes were isolated from the patient's skin under identical conditions. Isolated cells were cultured for the first passage in keratinocyte growth medium (KGM, Clonetics Co.), frozen, and stored in liquid nitrogen. Thawed cells were cultured through a second cell division in MCDB 153 medium, supplemented with $10 \mu \mathrm{g} / \mathrm{ml}$ of epidermal growth factor (EGF), $5.0 \mu \mathrm{g} / \mathrm{ml}$ of insulin, $5.0 \mu \mathrm{g} / \mathrm{ml}$ of transferrin, $25 \mu \mathrm{g} / \mathrm{ml}$ of bovine pituitary ex- 
tract, $50 \mathrm{U} / \mathrm{ml}$ of penicillin, and $50 \mu \mathrm{g} / \mathrm{ml}$ of streptomycin (Marinkovich et al. 1993). The cells at second or third passage were used throughout this study.

\section{Indirect immunofluorescence}

Indirect immunofluorescence was performed using anti-keratin 14 (Novacastra Laboratories, Newcastle-upon-Tyne, UK), antiinvolucrin (SY5) (Hudson et al. 1992), anti-type VII collagen (NP185) (Sakai et al. 1986) antibodies, and monoclonal antibody HD121 against HD1 (Owaribe et al. 1991; Hieda et al. 1992). Monoclonal antibody to plectin (7A8) and FITC-conjugated secondary antibody were purchased from Sigma. Immunoprecipitation of $\left[{ }^{35} \mathrm{~S}\right]$ methionine/cysteine-labeled keratinocyte proteins was performed as described previously (Marinkovich et al. 1992).

\section{cDNA synthesis}

Poly $(\mathrm{A})^{+}$mRNA was extracted directly from pelleted human keratinocytes $\left(\sim 2 \times 10^{6}\right.$ cells per preparation) using the Quickprep Micro mRNA purification kit (Pharmacia) according to the manufacturer's protocol. mRNA was stored in $80 \%$ ethanol at $-80^{\circ} \mathrm{C}$ until use. Rat epidermal mRNA was extracted by the same method directly from 10-12 cryostat sections, each $35 \mu \mathrm{m}$ thick. For reverse transcription, mRNA /equivalent to $\sim 5 \times 10^{5}$ cells) was recovered by precipitation, resuspended in $5 \mu$ l of DEPC treated $\mathrm{H}_{2} \mathrm{O}$ containing 40 units of RNAsin (Boehringer) and $1 \mu \mathrm{l}$ of a $1-\mathrm{mg} / \mathrm{ml}$ solution of oligo[ $\left.\mathrm{dT}_{[18-20)}\right]$ (Pharmacia), and heated to $70^{\circ} \mathrm{C}$ for $5 \mathrm{~min}$. The mixture was cooled to $42^{\circ} \mathrm{C}$ and $13 \mu \mathrm{l}$ of prewarmed reverse transcription mix was added (containing $4 \mu \mathrm{l}$ of $5 \times$ AMV-RT buffer, $1 \mu$ l of $20 \mathrm{~mm}$ dNTP, and 8 units of Promega AMV-RT). Following a 1-hr incubation at $42^{\circ} \mathrm{C}$, the reaction was heated to $70^{\circ} \mathrm{C}$ for $5 \mathrm{~min}$, cooled to $42^{\circ} \mathrm{C}$, an additional 8 units of AMV-RT was added, and the reaction incubated for $1 \mathrm{hr}$ at $42^{\circ} \mathrm{C}$. The resultant cDNA was used for PCR (0.5 $\mu$ l per reaction). This two-stage incubation was found to greatly enhance reverse transcription of the $14-\mathrm{kb}$ plectin message. In some cases, internal plectin-specific primers were used for reverse transcription, at a concentration of 50 nmoles per $20 \mu \mathrm{l}$ reaction; however, PCR amplification of $5^{\prime}$ regions of the plectin message from oligo(dT)-primed cDNA was possible.

\section{Polymerase chain reaction}

Initially, PCR was performed on rat epidermal cDNA using primers designed from the published rat mRNA sequence (Wiche et al. 1991). Many regions of the plectin mRNA (mainly in the $5^{\prime}$ half of the message) were found to amplify poorly or not at all using Taq polymerase, presumably because of the highly repetitive and GC-rich nature of the sequence. This was overcome using Boehringer Expand Long Range and Expand High Fidelity enzyme mixtures $(0.25 \mu \mathrm{l}$ per $50-\mu \mathrm{l}$ reaction) and the following extended program: $94^{\circ} \mathrm{C}$ for $2 \mathrm{~min} \times 1 ; 94^{\circ} \mathrm{C}$ for 10 sec, $50-60^{\circ} \mathrm{C}$ for $30 \mathrm{sec}, 68^{\circ} \mathrm{C}$ for $3 \mathrm{~min} \times 10 ; 94^{\circ} \mathrm{C}$ for $10 \mathrm{sec}$, $50-60^{\circ} \mathrm{C}$ for $30 \mathrm{sec}, 68^{\circ} \mathrm{C}$ for $3 \mathrm{~min}+20$-sec increment per cycle $\times 15-25 ; 72^{\circ} \mathrm{C}$ for $10 \mathrm{~min} \times 1$. This program was used to amplify fragments of 500-1000 bp, and for larger fragments (up to $6.5 \mathrm{~kb}$ ) the extension time was increased to $8 \mathrm{~min}$ and $0.75 \mu \mathrm{l}$ of enzyme mix used.

\section{Isolation of P1 genomic clones}

A 400-bp PCR derived from EST HSXS165 was used to screen a human genomic library (Genome Systems). Three P1 clones in
Escherichia coli strain NS3529 (cre + ) were isolated and designated 9108-9110, all of which were probed by PCR and found to contain sequences from both the $5^{\prime}$ and $3^{\prime}$ ends of the plectin cDNA. Restriction digests of the three clones showed that these overlap considerably (not shown). P1 clones were transferred into the cre $-E$. coli strain $\mathrm{DH} 10 \mathrm{~B}$ for propagation at a high copy and for improved sequencing template as recommended by Genome Systems. Briefly, this was carried out by production of a transducing phage by infecting the NS3529 clones with Plvirphage, recovering the $\mathrm{P} 1$ virus and subsequent transduction into $\mathrm{DH} 10 \mathrm{~B}$, according to the Genome Systems protocol. Sequencing quality plasmid was prepared from $4 \times 30-\mathrm{ml}$ cultures per clone, according to the Genome Systems plasmid preparation, except that spot dialysis of the purified plasmid was found not to improve the quality of direct sequencing significantly.

\section{DNA sequencing}

Fluorescent dye-terminator sequencing was performed using the ABI PRISM Ready Reaction kit (Perkin-Elmer) according to the manufacturers recommendations, and sequencing ladders were analyzed on an ABI 373 automated sequencer. PCR products were purified for sequencing using the QIAquick PCR purification kit (Qiagen) and -25-50 ng used per sequencing reaction for fragments in the size range $500-1000 \mathrm{bp} ; 50-100 \mathrm{ng}$ for fragments of size 1000-2000 bp; and 100-150 ng for fragments $>2000 \mathrm{bp}$. For direct sequencing of Pl clones $1.2 \mu \mathrm{g}$ of plasmid was used per reaction.

\section{RACE}

Both 5' and 3' RACE reactions were carried out using the Marathon cDNA Amplification Kit (Clontech). Adaptor-ligated double-stranded-cDNA was prepared from primary keratinocyte poly $(\mathrm{A})^{+}$mRNA, according to the Clontech protocol. Nested PCR was initially performed using Expand Long Range thermostable polymerase mix (Boehringer) using the conditions described above. The resultant products were gel purified using the QIAEX II gel extraction kit (Qiagen) and directly sequenced.

\section{DNA and protein sequence analysis}

Oligonucleotide primers for PCR and sequencing were designed using OLIGO 4.0 (National Biosciences, Inc.). DNA and predicted protein sequences were compiled, translated, and compared using the Genetics Computer Group (GCG) package (version 8, August 1994, Genetics Computer Group, Madison, WI). Sequence comparisons were performed using the GAP function within GCG. Data base searching was performed using the Basic Local Alignment Search Tool (BLAST) program (Altschul et al. 1990). GCG and BLAST were accessed on-line via The Medical Research Council's Human Gene Mapping Project (Hinxton Hall, Cambridge UK).

\section{Fluorescence in situ hybridization (FISH)}

Metaphase chromosomes were prepared from normal human lymphocytes using standard techniques. P1 DNA was labeled by nick translation with the BioNick labeling system (BRL). Biotin-labeled P1 DNA (250 ng) was used as probe. Pretreatment, hybridization, and washing of slides were performed as described previously (Veronese et al. 1995). Slides were analyzed with a Leitz fluorescence-equipped microscope, and images were acquired with a cooled CCD camera (Princeton Instruments) and IP-Lab Spectrum software (Signal Analytics). More 
than 20 DAPI-stained metaphases were analyzed to verify the localization of the probe.

\section{Acknowledgments}

We extend our special thanks to the patient and his family for their interest and participation in this work. We appreciate the assistance of the National EB Registry Northeast Clinical Site at the Rockefeller University Hospital for providing medical records, Ms. Linda Friedman, New York Hospital, for printing the electron micrographs, and Dr. David J. Weiss of Magee Rehabilitation Hospital (Philadelphia, PA) for the initial referral of this family to us. The work of Hans-Jürg Alder and his staff in The Nucleic Acid Facility, Kimmel Cancer Center, Jefferson Medical College, in carrying out the large amount of oligonucleotide synthesis and sequencing involved in this project is greatly appreciated. This work was supported by grants from the Cancer Research Campaign (grant SP2060 to EBL); The Wellcome Trust (037444/A/93/Z to E.B.L., R.A.J.E. and I.M.L.); Dystophic Epidermolysis Bullosa Reseach Association, UK (W.H.I.M. and E.B.L.); U.S. Public Health Service, National Institute of Health (J.U.).

The publication costs of this article were defrayed in part by payment of page charges. This article must therefore be hereby marked "advertisement" in accordance with 18 USC section 1734 solely to indicate this fact.

\section{Note added in proof}

Since the submission of this manuscript, we learned of a paper describing the cloning of the human plectin gene (Liu et al. $1996)$ and another report of plectin deficiency in MD-EBS (Gache et al. 1996). We have subsequently discovered a second homozygous frameshift mutation in an unrelated MD-EBS patient (Smith et al. 1996).

\section{References}

Altschul S.F., W. Gish, W. Miller, E.W. Myers, and D.J. Lipman. 1990 Basic local alignment search tool. J. Mol. Biol. 215: 403-410.

Brown A., N.G. Copeland, D.J. Gilbert, N.A. Jenkins, J. Rossant, and R. Kothary. 1994. The genomic structure of an insertional mutation in the dystonia musculorum locus. Genomics 20: 371-376.

Brown A., G. Bernier, M. Mathieu, J. Rossant, and R. Kothary. 1995. The mouse dystonia musculorum gene is a neural isoform of bullous pemphigoid antigen 1. Nature Genet. 10: 301-306.

Campbell, K.P. 1995. 3 muscular dystrophies-Loss of cytoskeleton extracellular matrix linkage. Cell 80: 675-679.

Christiano, A.M. and J. Uitto. 1996a. Molecular complexity of the cutaneous basement membrane zone. Revelations from the paradigms of epidermolysis bullosa. Exp. Dermatol. 5: $1-11$.

. 1996b. Molecular diagnosis of inherited skin disorders: The paradigm of dystrophic epidermolysis bullosa. Adv. Dermatol. 11: 199-214.

Cooper, D.N. 1993. Human gene mutations affecting RNA processing and translation. Ann. Med. 25: 11-17.

Cui, Y., K.W. Hagan, S. Zhang, and S.W. Peltz. 1995. Identification and characterization of genes that are required for the accelerated degradation of mRNAs containing a premature translational termination codon. Genes \& Dev. 9: 423-436.
Epstein, E.H. Jr. 1992. Molecular genetics of epidermolysis bullosa. Science 256: 799-803.

Errante, L.D., G. Wiche, and G. Shaw. 1994. Distribution of plectin, an intermediate filament-associated protein, in the adult rat central nervous system. I. Neurosci. Res. 37: 515528.

Fine, J.-D., J. Stenn, L. Johnson, T. Wright, H-G.O. Bock, and Y. Horiguchi. 1989. Autosomal recessive epidermolysis bullosa simplex: generalized phenotypic features suggestive of junctional or dystrophic epidermolysis bullosa, and association with neuromuscular diseases. Arch. Dermatol. 125: 931938.

Fine, J.-D., E.A. Bauer, R.A. Briggaman, D.M. Carter, R.A.J. Eady, N.B. Esterly, K.A. Holbrook, S. Hurvitz, L. Johnson, A. Lin, R. Pearson, and V.P. Sybert. 1991. Revised clinical and laboratory criteria for subtypes of inherited epidermolysis bullosa: a consensus report by the subcommittee on diagnosis and classification of the National Epidermolysis Bullosa Registry. J. Am. Acad. Dermatol. 24: 119-135.

Foisner, R., B. Feldman, L. Sander, G. Seifert, U. Artlieb, and G. Wiche. 1994. A panel of monoclonal-antibodies to rat plectin - distinction by epitope mapping and immunoreactivity with different tissues and cell lines. Acta Histochem. 96: 421438.

Fuchs, E. 1992. Genetic skin disorders of keratin. J. Invest. Dermatol. 99: 671-674.

Fujiwara, S., H. Shinkai, S. Takayasu, K. Owaribe, S. Tsukita, and T. Kageshita. 1992. A case of subepidermal blister disease associated with autoantibody against $450 \mathrm{kD}$ protein. $J$. Derm. 19: 610-613.

Gache, Y., S. Chavanas, J.P. Lacour, G. Wiche, K. Owaribe, G. Meneguzzi, and J.P. Ortonne. 1996. Defective expression of plectin/HD1 in epidermolysis bullosa simplex with muscular dystrophy. J. Clin. Invest. 97: 2289-2298.

Garrod, D.R. 1993. Desmosomes and hemidesmosomes. Curr. Opin. Cell Biol. 5: 30-40.

Gil, S.G., T.A. Brown, M.C. Ryan, and W.G. Carter. 1994. Junctional epidermolysis bullosa: Defects in expression of epiligrin $/$ nicein $/ \mathrm{kalinin}$ and integrin $\beta 4$ that inhibit hemidesmosome formation. J. Invest. Dermatol. 103: 31S-38S.

Green, K.J., M.L.A. Virata, G.W. Elgart, J.R. Stanley, and D.A.D. Parry. 1992. Comparative structural analysis of desmoplakin, bullous pemphigoid antigen and plectin-Members of a new gene family involved in organisation of intermediate filaments. Int. J. Biol. Macromol. 14: 145-153.

Guo, L., L. Degenstein, J. Dowling, Q.C. Yu, R. Wollman, B. Perman, and E. Fuchs. 1995. Gene targeting of BPAG1: Abnormalities in mechanical strength and cell migration in stratified epithelia and neurologic degeneration. Cell 81: 233-243.

Hieda, Y., Y. Nishizawa, J. Uematsu, and K. Owaribe. 1992. Identification of a new hemidesmosomal protein, HD1: A major, high molecular mass component of isolated hemidesmosomes. J. Cell Biol. 116: 1497-1506.

Hintner, H. and K. Wolff. 1982. Generalized atrophic benign epidermolysis bullosa. Arch. Dermatol. 118: 375-384.

Hudson, D.L., K.L. Weiland, T.P. Dooley, M. Simon, and F.M. Watt. 1992. Characterization of eight monoclonal antibodies to involucrin. Hybridoma 11: 367-369.

Jones, J.C. and K.J. Green. 1991. Intermediate filament-plasma membrane interactions. Curr. Opin. Cell Biol. 3: 127-132.

Jones, I.C., M.A. Kurpakus, H.M. Cooper, and V. Quaranta. 1991. A function for the integrin a6b4 in the hemidesmosome. Cell Regul. 2: 427-438.

Jonkman, M.F., M.C.J.M. de Jong, K. Heeres, H.H. Pas, J.B. Vandermeer, K. Owaribe, A.M.M. Develasco, C.M. Niessen, and 
A. Sonnenberg. 1995. 180-kD bullous pemphigoid antigen (BP180) is deficient in generalized atrophic benign epidermolysis bullosa. J. Clin. Invest. 95: 1345-1352.

Kletter, G., O.B. Evans, J.A. Lee, B. Melvin, A.B. Yates, and H.-G.O. Bock. 1989. Congenital muscular dystrophy and epidermolysis bullosa simplex. I. Pediatr. 114: 104-107.

Krawczak, M. and D.N. Cooper. 1991. Gene deletions causing human genetic disease-Mechanisms of mutagenesis and the role of local DNA-sequence environment. Hum. Genet. 128: 425-441.

Lestringant, G.G., S.R. Akel, and K.I. Qayed. 1992. The pyloric atresia-junctional epidermolysis bullosa syndrome. Arch. Dermatol. 128: 1083-1086.

Li, K., K. Tamai, E.M.L. Tan, and J. Uitto. 1993. Cloning of type XVII collagen: Complementary and genomic DNA sequences of mouse 180-kilodalton bullous pemphigoid antigen (BP180) predict an interrupted collagenous domain, a transmembrane segment, and unusual features in the $5^{\prime}$-end of the gene and the $3^{\prime}$-untranslated region of the mRNA. $J$. Biol. Chem. 268: 8825-8834.

Lin, A.N. and D.M. Carter. 1992. Epidermolysis bullosa. Basic and clinical aspects. Springer-Verlag, New York, NY.

Liu, C-G., C. Maercker, M.J. Castonon, R. Hauptmann, and G. Wiche. 1996. Human plectin-Organization of the gene, sequence analysis and chromosome location (8q24). Proc. Nat1. Acad. Sci. 93: 4278-4283.

Marinkovich, M.P., G.P. Lunstrum, D.R. Keene, and R.E. Burgeson. 1992 The dermal-epidermal junction of human skin contains a novel laminin variant. J. Cell Biol. 119: 695-703.

Marinkovich, M.P., D.R. Keene, C.S. Rimberg, and R.E. Burgeson. 1993. Cellular origin of the dermal-epidermal junction. Dev. Dynam. 197: 255-267.

McGrath, J.A., B. Gatalica, A.M. Christiano, K.H. Li, K. Owaribe, J.R. McMillan, R.A.J. Eady, and J. Uitto. 1995. Mutations in the $180-\mathrm{kD}$ bullous pemphigoid antigen (BP180), a hemidesmosomal transmembrane collagen (COL17A1), in generalized atrophic benign epidermolysis bullosa. Nature Genet. 11: 83-86.

McGrath, J.A., T. Darling, B. Gatalica, G. Pohliagnbo, H. Hintner, A.M. Christiano, K. Yancey, and J. Uitto. 1996. A homozygous deletion mutation in the $180-\mathrm{kD}$ bullous pemphigoid antigen gene (BP180) in a family with generalized atrophic benign epidermolysis bullosa. I. Invest. Dermatol. 106: 771-774.

McLean, W.H.I. and E.B. Lane. 1995. Intermediate filaments in disease. Curr. Opin. Cell Biol. 7: 118-125.

Nagle, R.B., J.S. Hao, J.D. Knox, B.L. Dalkin, V. Clark, and A.E. Cress. 1995. Expression of hemidesmosomal and extracellular matrix proteins by normal and malignant human prostate tissue. Am. J. Pathol. 146: 1498-1507.

Niemi, K.-M., H. Sommer, M. Kero, L. Kanerva, and M. Haltia. 1988. Epidermolysis bullosa simplex associated with muscular dystrophy with recessive inheritance. Arch. Dermatol. 124: 551-554.

Owaribe, K., Y. Nishizawa, and W.W. Franke. 1991. Isolation and characterization of hemidesmosomes from bovine corneal epithelial cells. Exp. Cell Res. 192: 622-630.

Sakai, L.Y., D.R. Keene, N.P. Morris, and R.E. Burgeson. 1986. Type VII collagen is a major component of anchoring fibrils. J. Cell Biol. 103: 1577-1586.

Sambrook, J., E.F. Fritsch, and T. Maniatis. 1989. Molecular cloning. A laboratory manual. Cold Spring Harbor Laboratory Press, Cold Spring Harbor, NY.

Sawamura, D., K. Li, M-L. Chu and J. Uitto. 1991. Human bullous pemphigoid antigen (BP230): Amino acid sequences deduced from cloned cDNAs predict biologically important peptide segments and protein domains. I. Biol. Chem. 266: 17784-17790.

Seifert, G.J., D. Lawson, and G. Wiche. 1992. Immunolocalisation of the intermediate filament-associated protein plectin at focal contacts and actin stress fibers. Eur. J. Cell Biol. 59: $138-147$.

Skalli, O., J.C.R. Jones, R. Gagescu, and R.D. Goldman. 1994. IFAP300 is common to desmosomes and hemidesmosomes and is a possible linker of intermediate filaments to these junctions. J. Cell Biol. 125: 159-170.

Smith, F.J.D., R.A.J. Eady, J.R. McMillan, I.M. Leigh, J.F. Geddes, E.L. Rugg, D.P. Kelsell, S.P. Bryant, N.K. Spurr, G. Kirtschig, G. Milana, A.G. de Bono, K. Owaribe, G. Wiche, L. Pulkkinen, J. Uitto, W.H.I. McLean, and E.B. Lane. 1996. Plectin deficiency: Hereditary basis for muscular dystrophy with epidermolysis bullosa. Nature Genet. (in press.)

Stepp, M.A., S. Spurr-Michaud, A. Tisdale, J. Elwell, and I.K. Gipson. 1990. $\alpha 6 \beta 4$ integrin heterodimer is a component of hemidesmosomes. Proc. Natl. Acad. Sci. 87: 8970-8974.

Uitto, J. and A.M. Christiano. 1992. Molecular genetics of the cutaneous basement membrane zone. Perspectives on epidermolysis bullosa. J. Clin. Invest. 90: 687-692.

Uitto, J., J.A. McGrath, L. Pulkkinen, and A.M. Christiano. 1995. Molecular basis of the junctional forms of epidermolysis bullosa, a disorder of the cutaneous basement membrane zone. In: Proceedings of the Seventh International Symposium on Basement Membranes, National Institutes of Health, Bethesda, MD. pp. 257-269.

Veronese, M.L., M. Ohta, J. Finan, P.C. Nowell, and C.M. Croce. 1995. Detection of myc translocations in lymphoma cells by fluorescence in situ hybridization with yeast artificial chromosomes. Blood 85: 2132-2138.

Vidal, F., D. Aberdam, C. Miquel, A.M. Christiano, L. Pulkkinen, J. Uitto, J.P. Ortonne, and G. Meneguzzi. 1995. Integrin $\beta 4$ mutations associated with junctional epidermolysis bullosa with pyloric atresia. Nature Genet. 10: 229-234.

Wiche, G., B. Becker, K. Luber, G. Weitzer, M.J. Castanon, R. Hauptmann, C. Stratowa, and M. Stewart. 1991. Cloning and sequencing of rat plectin indicates a $466-\mathrm{kD}$ polypeptide chain with a three-domain structure based on a central alpha helical coiled-coil. J. Cell Biol. 114: 83-99.

Wiche, G., D. Gromov, A. Donovan, M.J. Castanon, and E. Fuchs. 1993. Expression of plectin mutant cDNAs in cultured cells indicates a role of $\mathrm{COOH}$-terminal domain in intermediate filament association. J. Cell Biol. 121: 607619. 


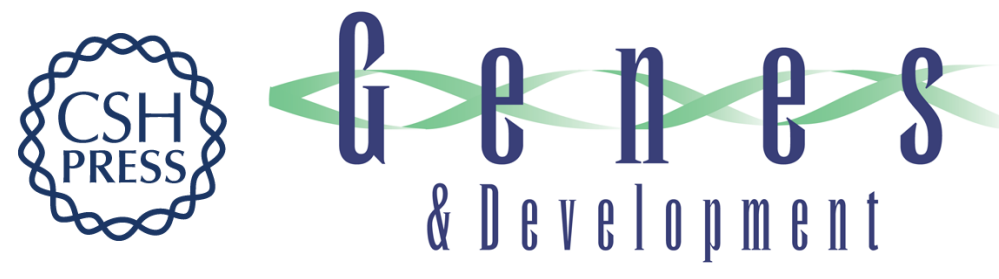

\section{Loss of plectin causes epidermolysis bullosa with muscular dystrophy: cDNA cloning and genomic organization.}

W H McLean, L Pulkkinen, F J Smith, et al.

Genes Dev. 1996, 10:

Access the most recent version at doi:10.1101/gad.10.14.1724

References This article cites 49 articles, 13 of which can be accessed free at:

http://genesdev.cshlp.org/content/10/14/1724.full.html\#ref-list-1

License

Email Alerting

Service

Receive free email alerts when new articles cite this article - sign up in the box at the top right corner of the article or click here.

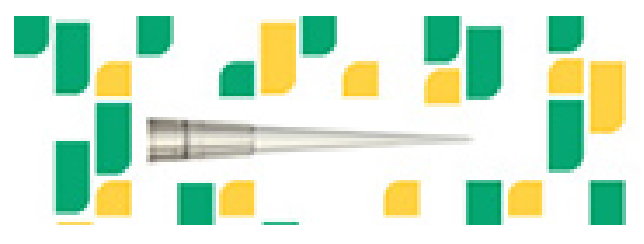

Focused on your science. 